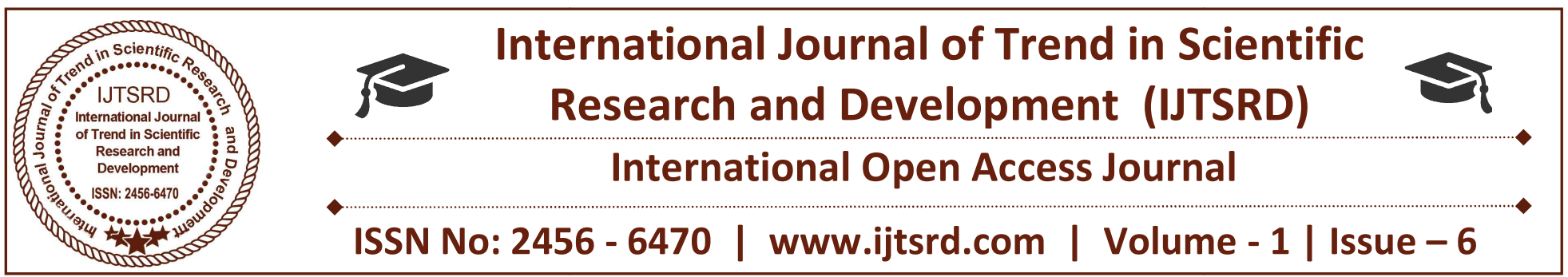

\title{
A Study on Financial Performance of BDCC Bank Ltd
}

\author{
Prof. Kesarisinh S. Parmar \\ Associate Professor in Accountancy \\ Government Arts and Commerce College, Kadoli
}

\begin{abstract}
Co-operative banking system is basically an imported concept but it has come to occupy a pivotal and prominent role in the economic liberation of millions of people of our nation. It has emerged as a social and healthy banking institution providing need-based quality banking services essentially to the middle and lower middle classes and the marginalized sections of the society those who consists 75 percent of our country. Co-operative Banks have assisted in boosting the growth rate of Indian economy by providing a fillip to agricultural production in the country by making available cheap and hassle free agricultural finance. A healthy co operative banking system is essential for Indian economy striving to achieve growth and remain stable in competitive global business environment. In this juncture the performance of these institutions has been than satisfactory and is deteriorating rapidly. On the other hand some institutions doing their services remarkably. In this way BDCC bank Ltd in Banaskantha district renders its services and meeting the credit requirement of rural, semi urban and urban customers. With this back ground data have been collected and analyzed the financial performance and operational efficiency of Banaskantha District Central Co-operative Bank Ltd (BDCC Bank).
\end{abstract}

Keywords: Co-operative Bank, Financial performance, Credit-Movement.

\section{INTRODUCTION}

At present Co-operative banks are giving vital contribution in Indian economy. Co-operative banks accept deposit and provide it in the form of loan or credit to needy people. These banks also started

various facilities just like business banks. The development of co-operative banks is considerable in four leading states of India named Gujarat, Maharastra, Karnatak and Tamilnadu. Co-operative banks play the role as business banks. Credits of cooperative banks have been more multipurpose, productive, conclusive and purposeful. Co-operative banks formed special schemes for helping poor and economically weaker section of the society in their economic and social development as well as collecting their savings. They have started new service like providing loans according to need; with low interest rate and certain percentage of total credit. Compare to nationalize banks co-operative banks contributed vitally for satisfaction of needs of socially backward people.

Co-operative Banks failure has been relatively high in recent years. Bulging of non-performance assets is one of the reasons for the failure of co-operative banks. The other reasons are falling increasing the expenses and operating costs. In the co-operative credit structure of the district central co-operative banks occupy a position. DCCBs have playing role of intermediate between the state co-operative bank and the primary agricultural societies. The success of the DCCB largely depends on own financial strength. It is also depended on the apex body and their borrowers. The aim of the district central cooperative bank is to satisfy the need of credit requirements of their society's members. The District central co-operative banks act is as an intermediary between primary societies and money market. Deposit mobilization, lending operations, repayment 
performance and utilization of funds are as the key elements, that decides the success of the DCCBs.

\section{REVIEW OF RELATED LITERATURE}

Chander and Chandel (2010), in their study of financial viability and performance of cooperative credit institutions in Haryana from 1997-98 to 200809 were analyzed and discussed with the help of using Financial Analysis and Z-score analysis. For their study they find out profitability, liquidity, solvency, efficiency and risk are the key factors to check the financial position of the banks. Four different ratios were calculated and analyzed in each sector. The findings of the study reveal that four District Central Cooperative Banks has not been functioning in a successful way with its fifty branches. The banks find better position in one parameter and in other analysis it not found so good. On the other hand Z-score analysis was at week point of all the banks and become financially weak also were suffering from the financial mismanagement because of underutilization of resources.

Gnanasekaran. E, Dr. M. Anbalgan, N. Abdul Nazar, (2013), "Cooperative Banks success and growth in Vellore District-Statistical Analysis", in this study reveals that the position of Membership, the share capital position, NPAs, Loans and advance of the bank and profitability position of the bank are tested and verified with the help of statistical tools and ratio analysis. The overall position showed a significant growth and concluded that it is in a progressive way. The study concludes that the bank is role model for other banks and the bank is occupied in eighth place and it served a best role and became the model for other banking industries in this district.

\section{OBJECTIVES OF THE STUDY:}

$>$ To know the progress of Banaskantha District Central Co-operative bank.

$>$ To know the growth of Membership, Share capital, Deposit mobilization, borrowings, Investments, Business, Owen fund, Working Capital, loans and advances, Net Profit and Gross NPA of the BDCC Bank.

$>$ To know about the profitability position of BDCC Bank.

$>$ To know about the liquidity position of BDCC Bank.

To know about the solvency position of BDCC Bank.

\section{METHODOLOGY OF THE STUDY:}

This study is based on the secondary data. The data were collected from the websites, books and annual reports. In order to test the hypotheses the ratio analysis, t-test correlation and percentage analysis are used.

\section{HYPOTHESES OF THE STUDY :}

Based on the objectives the following hypotheses are formulated and tested.

There is no significance between share capital and profit.

$>$ There is no significance between Business and profit.

$>$ There is no significance between share capital and membership. 
International Journal of Trend in Scientific Research and Development (IJTSRD) ISSN: 2456-6470

\section{RESULT AND ANALYSIS :}

Explains overall performance of the bank.

\section{Table 1: Overall Performance of BDCC Bank}

\begin{tabular}{|c|c|c|c|c|c|c|c|c|c|}
\hline SI.No & Particulars & $2010-11$ & $2011-12$ & $2012-13$ & $2013-14$ & $2014-15$ & Mean & S.D. & C.V. \\
\hline 1 & Membership & 2,938 & 3,070 & 3,072 & 3,072 & 3,072 & 3,045 & 59.7093 & 1.96 \\
\hline 2 & Share capital & $3,867.51$ & $4,107.25$ & $4,431.68$ & $4,948.50$ & $5,614.31$ & $4,593.85$ & 699.60 & 15.23 \\
\hline 3 & Reserves & $5,380.57$ & $6,027.39$ & $6,659.33$ & $7,184.32$ & $7,867.12$ & $6,623.75$ & 969.87 & 14.64 \\
\hline 4 & Deposits & $74,324.21$ & $79,332.81$ & $87,183.56$ & $93,089.48$ & $1,11,437.19$ & $89,073.45$ & $14,424.43$ & 16.19 \\
\hline 5 & Borrowings & $18,023.15$ & $25,640.59$ & $34,289.74$ & $41,310.37$ & $38,690.35$ & $31,590.84$ & $9,639.04$ & 30.51 \\
\hline 6 & Investment & $15,773.51$ & $20,691.72$ & $20,634.41$ & $24,849.03$ & $33,125.28$ & $23,014.79$ & $6,501.64$ & 28.25 \\
\hline 7 & Business & $1,33,620.03$ & $1,41,006.63$ & $1,59,237.22$ & $1,86,065.13$ & $2,09,269.51$ & $1,65,839.70$ & $31,597.46$ & 19.05 \\
\hline 8 & Own fund & $9,248.08$ & $10,134.64$ & $11,091.01$ & $12,132.82$ & $13,481.43$ & $11,217.60$ & $1,660.60$ & 14.80 \\
\hline 9 & $\begin{array}{l}\text { Working } \\
\text { Capital }\end{array}$ & $1,13,000$ & $1,25,400$ & $1,44,700$ & $1,60,300$ & $1,81,900$ & $1,45,060.00$ & $27,404.07$ & 18.89 \\
\hline 10 & $\begin{array}{l}\text { Loan and } \\
\text { advances }\end{array}$ & $59,295.82$ & $61,673.82$ & $72,053.66$ & $92,975.65$ & $97,832.32$ & $76,766.25$ & $17,760.42$ & 23.14 \\
\hline 11 & Net profit & 535.00 & 555.00 & 575.00 & 825.00 & 830.00 & 664.00 & 149.93 & 22.58 \\
\hline 12 & Gross NPA & $3,569.42$ & $3,366.68$ & $3,331.51$ & $3,794.40$ & $4,813.96$ & $3,775.19$ & 609.40 & 16.14 \\
\hline
\end{tabular}

Sources: Annual reports of BDCCB from 2010-11 to 2014-15

The Banaskantha District Central co-operative bank had 2,993 members in year 2010-11, It was reached at 3,072 in 2014-15. The share capital of the bank in year 2010-11 was ₹ 3,867 and ₹ 5,614 seen in year 201415.Likewise, hike in share capital was ₹ $1,746.8$ lakh in last five years. In year 2010-11 reserved balance was ₹ 5,380 and in 2014-15 it was ₹ 7,867.12. During the period of research, average reserved balance was ₹ 6,623.75. In year 2010-11, the deposit was ₹ $74,324.21$ when in year 2014-15 it was of ₹ $1,11,437$. The deposits were continuously increasing in this bank which is really the good thing. The total borrowings in year 2010-11 was ₹ 18,023 lakh when in year 2014-15 it was of ₹ 38,693 lakh. In this bank borrows was increased more as we can see.

The BDCC bank never depended on the outside borrowings. It is remarkable achievement of this Bank. Another progressing indication of BDCC Bank is the deposits mobilized by them. It indicates the trust and faith in the BDCC Bank. During the study, average investments of the bank were ₹ 23,014.79 lakh. Continuously the investments of the bank were increasing. The deposits of the bank and advance's addition called as business. The total business of the bank in the year 2010-11 was ₹ 1,33,620.03 lakh and in year 2014-15 it was of ₹ 1, 65,839.70. Addition of Share capital and reserve are known as equity fund. In this bank the equity fund was of ₹ 11,217.60 lakh. In year 2010-11 the working capital was of ₹ 1,13,000 and in year 2014-15 it was of ₹ $1,81,900$ the average capital was seen of ₹ 1,45,060. In year 2010-11 loan and advance had been seen of ₹ 59,295.82, when in 2014-15 it was seen of ₹ 97,975.65. During the period of study there was found the hike of ₹ 38,679.83 lakh in the loan and advance. Net profit was increased day by day. Average net profit was seen of ₹ 664 lakh. Total N.P.A was decreased during the years 2010-11 to 2012-13, when in years 2013-14 and 2014-15 it was looks increased. The average N.P.A of the bank was seen of ₹ 3,775.19. 
One more fact worth noting is that the reserves and share capital are sufficient as their source. The BDCC bank never depended on the outside borrowings. It is remarkable achievement of this Bank. Another indicator of progress of BDCC Bank is the deposits mobilized by them. It indicates the trust and faith in the BDCC Bank. It is Good health progress of this bank.

\section{Profitability Ratio:}

The foundation of the any financial institute is based on the profitability. The profitability of the bank is finding with the help of different profit related ratios. The Following table shows the calculations of the ratios to find the profitability of the bank.

\section{Table 2: Profitability Ratio}

\begin{tabular}{|l|l|l|l|l|l|l|l|}
\hline $\begin{array}{l}\text { SI } \\
\mathbf{N} \\
0\end{array}$ & Year & $\begin{array}{l}\text { NP/ } \\
\text { TI }\end{array}$ & $\begin{array}{l}\text { NP/ } \\
\text { TD }\end{array}$ & $\begin{array}{l}\text { NP/ } \\
\text { SPR } \\
\text { EAD } \\
\text { Ratio }\end{array}$ & $\begin{array}{l}\text { NP/ } \\
\text { TA }\end{array}$ & $\begin{array}{l}\text { NP/ } \\
\text { NW }\end{array}$ & $\begin{array}{l}\text { NP/ } \\
\text { WC }\end{array}$ \\
\hline $\mathbf{1}$ & $\begin{array}{l}2010 \\
-11\end{array}$ & 5.67 & 0.90 & 12.86 & 0.47 & 5.78 & 0.47 \\
\hline $\mathbf{2}$ & $\begin{array}{l}2011 \\
-12\end{array}$ & 5.39 & 0.90 & 11.85 & 0.44 & 5.48 & 0.44 \\
\hline $\mathbf{3}$ & $\begin{array}{l}2012 \\
-13\end{array}$ & 4.28 & 0.80 & 18.02 & 0.39 & 5.18 & 0.40 \\
\hline $\mathbf{4}$ & $\begin{array}{l}2013 \\
-14\end{array}$ & 4.97 & 0.89 & 13.53 & 0.51 & 6.80 & 0.51 \\
\hline $\mathbf{5}$ & $\begin{array}{l}2014 \\
-15\end{array}$ & 5.74 & 0.85 & 13.26 & 0.43 & 6.16 & 0.46 \\
\hline Average & 5.21 & 0.87 & 13.90 & 0.45 & 5.88 & 0.46 \\
\hline
\end{tabular}

Sources: Annual reports of BDCCB from 2010-11 to 2014-15

$(\mathrm{NP}=$ Net Profit, $\mathrm{TI}=$ Total Income, $\mathrm{TD}=$ Total Deposit, Spread Ratio=Interest earned-interest paid, TA=Total Assets, NW $=$ Net worth $=$ Capital + Reserves, $\mathrm{WC}=$ Working Capital)

The ratios of net profit with total deposits, net profit with spread ratio, net profit with total advances, net profit with net worth, and net profit with working capital are use to measure bank's profit net profit with total income. The net profit of the bank fluctuates from have been in a progressive trend. In year 201011 net profit was 5.67 in comparison with income. When in 2014-15 this was seen at 5.74. Net profit in comparison with total income seen less in year 201213 and it was 4.28 when net profit in comparison with total income was seen 5.21 Average net profit was seen 0.87 in comparison with total deposit. This ratio was decreased gradually. Net profit and the spread ratio was fluctuates many times because from year 2010-11 to during 2013-14 this ratio was seen 12.86, $11.85,18.02$, and 13.53 . The average ratio of the net profit with spread was seen 13.90. Ratio of Net profit to spread ratio is the difference between interest earned and interest paid. Spread can be considered as the net profit of bank, it gives clear picture of profitability of the bank. Ratio of net profit to spread will indicate the relation between spread and net profit, higher ratio will indicate better profitability position of the bank.

Net profit in comparison with the total property from 2010-11 during to 2014-15 it was seen $0.47,0.44$, $0.39,0.51$ and 0.43 . It means net profit was found fluctuating in comparison with the total properties. When the average ratio was seen 0.45 . Average net profit 5.88 in comparison with the net worth.net profit was seen stable in comparison with the net worth. In year 2010-11 net profit was seen 0.47 in comparison with working capital which decreased in year 2011-12 and 2012-13 and was seen 0.44 and 0.40. After that it was increased 0.51 in 2013-14 and seen decreased 0.46 in year 2014-15. Net profit with working capital ratio was seen fluctuated when this ratio was seen average 0.46 .

\section{Liquidity Position:}

It is important to maintain the stability in liquidity position of the Bank. If the liquidity has not been stable then it's difficult to pay the debt. The liquidity of bank is finding on the basis of current assets and current debt. Table- 2 shows the liquidity ratios.

Table 3: Liquidity Position

\begin{tabular}{|l|l|l|l|}
\hline SI. No & Year & $\begin{array}{l}\text { Current } \\
\text { Ratio }\end{array}$ & $\begin{array}{l}\text { Credit } \\
\text { Deposit Ratio }\end{array}$ \\
\hline $\mathbf{1}$ & $2010-11$ & 1.11 & 79.78 \\
\hline $\mathbf{2}$ & $2011-12$ & 1.00 & 77.74 \\
\hline $\mathbf{3}$ & $2012-13$ & 0.94 & 82.65 \\
\hline $\mathbf{4}$ & $2013-14$ & 0.72 & 99.88 \\
\hline $\mathbf{5}$ & $2014-15$ & 0.82 & 87.79 \\
\hline \multicolumn{2}{|l|}{ Average } & 0.92 & 85.57 \\
\hline
\end{tabular}

Sources: Annual reports of BDCCB from 2010-11 to 2014-15 
The above table shows that the current ratio has increase gradually over the study period. In the year 2010-11 the liquidity ratio was 1.11 times, it has raised to 1.00 times in 2011-12. It is observed that the proportions of current Assets to current Liabilities are not uniform. The thumb rule of $2: 1$ is not maintained during last 5 year. The BDCC Bank neither has superfluous liquid fund, nor has below the danger line, it is just maintaining a safer strategy during recent year.

The average Credit-Deposit ratio of the study unit over the study period is 85.57 percent. The maximum percentage of ratio is 99.88 in 2013-14 and minimum percentage is 77.74 in the year 2011-12. Though the percentage varies, it remained well above the standard norms of 70 percent.

\section{Solvency Ratio:}

Solvency ratio is one of the various ratios used to measure the ability of a company to meet its long term debts. The economical solvency of the bank is examines on the basis of the ratios of the economical solvency. Moreover, the solvency ratio quantifies the size of a company's after tax income, not counting non-cash depreciation expenses, as contrasted to the total debt obligations. Following table -3 shows the solvency ratios of the bank.

\section{Table 4: Solvency Ratio}

\begin{tabular}{|l|l|l|l|}
\hline SI. No & Year & $\begin{array}{l}\text { Debt Equity } \\
\text { Ratio }\end{array}$ & $\begin{array}{l}\text { Dept Total } \\
\text { Fund }\end{array}$ \\
\hline $\mathbf{1}$ & $2010-11$ & 9.99 & 86.35 \\
\hline $\mathbf{2}$ & $2011-12$ & 10.36 & 88.18 \\
\hline $\mathbf{3}$ & $2012-13$ & 10.95 & 88.60 \\
\hline $\mathbf{4}$ & $2013-14$ & 11.08 & 87.13 \\
\hline $\mathbf{5}$ & $2014-15$ & 9.33 & 87.24 \\
\hline \multicolumn{2}{|l|}{ Average } & 10.34 & 87.50 \\
\hline
\end{tabular}

Sources: Annual reports of BDCCB from 2010-11 to 2014-15

The Debt-equity ratio was seen 9.99 in year 2010 . This was increased gradually till the year 2013-14. But in 2014-15 it was decrees and come down at 9.33. The average ratio of the Debt-equity was seen 10.34. This ratio is explains that the bank maintain balanced between the debt and equity. The debt/equity ratio tends to have above 2. This is more than the acceptable ratio in India. So it can be inferred that the proportion of debt is said to be high which indicates high average of the study unit. Total average ratio of the debt was seen 87.50. It means in comparison of debt with the total deposits, the debt seen $87.50 \%$. From year 2010-11 to 2012-13 it gradually increased and in year 2013-14 it was decreased gradually.

\section{Test of Significance}

$>\mathrm{H} 0=$ There is no significance between share capital and profit.

$>\mathrm{H} 0=$ There is no significance between business and profit.

$>\mathrm{H} 0=$ There is no significance between share capital and membership.

\section{T-test Table}

\begin{tabular}{|l|l|l|l|}
\hline Factors & T-test & T-tab & Result \\
\hline $\begin{array}{l}\text { Share Capital with } \\
\text { Profit }\end{array}$ & 9.9 & 2.77 & Rejected \\
\hline Business with Profit & 0.0003 & 2.77 & Accepted \\
\hline $\begin{array}{l}\text { Share capital with } \\
\text { Membership }\end{array}$ & 0.006 & 2.77 & Accepted \\
\hline
\end{tabular}

$>$ There is significant difference between share capital and profit.

$>$ There is no significant difference between business and profit.

$>$ There is no significant difference between share capital and membership.

As per shown in t-test table, the value of $\mathrm{T}$ and $\mathrm{T}-\mathrm{Tab}$ shows the difference between the share capital and net profit Because T-Tab's value is 2.77 and the value of T-Test is 9.9 . As shown it is more than the T-Tab. When looking at net profit and business, TTab's value is less than the T-Test value Because TTab's value is 2.77 when T-Test's value is 0.0003 . it means there is not a huge difference between the net profit and the progress of the business. The value of the share capital and T-Test of the membership is 0.0006 which is less than the 2.77 it means there is not any large difference found between the share capital and membership during the study.

\section{CONCLUSIONS:}

In this research study was done on the many financial sides of the bank and its profitability, liquidity, and hallucinations of the solvency. The overall performance and the financial condition are seen satisfactory. Profitability of the bank is looks very 
stable but it is to be desirable that spread ratio and total property will be increased. Liquidity of the bank is less if we see the current ratio of the bank which is necessary to increase. It's important to use maximum deposit of the bank. So the financial flow of the bank should be stable. Outer debt was decreased in comparison with the equity fund of the bank but grossly situation of the bank is stable. The overall performance and the financial condition are seen satisfactory.

An analysis of solvency ratios reveals that bank is performing its operations efficiently, there lies a scope to improve its operations so that it become more efficient. From the solvency ratios it can be inferred that the bank stands on a sound footing. Thus it can be said that Banaskantha District Central Co-operative bank achieved a significant growth in profits and showed a good performance in banking operations in the last phase of this period. One can concludes the bank can retain its dominating position in the years ahead like the past due to the stiff competition.

\section{REFERENCES:}

1) Amit Basak (2009), "Performance Appraisal of Urban Cooperative Banks: A Case Study", IUP journal of Accounting Research and Audit Practices. Year 2009.

2) Anagol malati-"Banking in Gujarat", Himalaya publishing house, Mumbai.(2000).

3) Chander Ramesh and Chandel Jai Kishan (2010), "Financial viability of an Apex Cooperative Credit Institution - A Case Study of the HARCO Bank." Asia-pacific Business review Vol. VI.No.2, AprilJune-2010. Pp 61-70.

4) Dash. D. K. (2000), "Financial Performance Evaluation through Ratio Analysis - A Case of Nawanozar Cooperative Bank, Jamnagar (Gujarat)." Indian Cooperative review, Vol.37, No.3, January,pp 162-170.

5) Sami uddin and mahfoozur rahmaan,(2001) cooperative sector in India, S.chand \& company L.td, ram nagar, new delhi.

6) Singh ram Binod, gandhian approach to development Planning (2006), New Delhi, Concept Publications.

7) Ganesan N. (2009), "Data Envelopment Analysis of State and District Cooperative Banks in India: Exploratory Rsults" IUP Journal of Bank management. Year-2009.
8) Gurucharan Singh and sukhmani (2011), “An Analytical Study of productivity and Profitability of District central Cooperative Banks in Punjab." Journal on Banking Financial Services and Insurance research, Vol.1 Issue 3 (june 2011), pg 128-142.

9) T. Unnamalai (2014), "A Study on financial performance of TDCC bank ltd." Tamil Nadu.

10) Reports on trends and Progress of Banking in India Published by RBI-Mumbai.

11) Annual reports of Banaskantha District central Co-operative Bank Ltd., Year 2010-11 to 2014-15. 